\title{
RICHARD R. JOHN \\ Projecting Power Overseas: U.S. Postal Policy and International Standard-Setting at the 1863 Paris Postal Conference
}

In May 1863, representatives from the fifteen countries that generated 95 percent of the world's correspondence met in Paris to devise a set of common standards for international postal communications. ${ }^{1}$ The impetus for this meeting, which would become known as the Paris Postal Conference, originated not in France, nor in Great Britain, nor even in Prussia. ${ }^{2}$ Rather, it was the brainchild of a little-known U.S. postal administrator-turned-lawmaker, John A. Kasson. In the previous year, Kasson had persuaded the U.S. postmaster general, Montgomery Blair, to recruit the U.S. secretary of state William Seward to convene an international meeting on postal standard-setting. Originally, Kasson assumed that this meeting would be convened in Brussels, Belgium, a logical site, since Brussels had hosted many international forums, including a statistical congress that had briefly discussed international postal reform in $1853 .{ }^{3}$ Yet this was not to be. At the request of the U.S. State Department, and presumably to mollify the French government, since France's geographical position gave it a central role in any international negotiation involving transnational postal rates, Kasson agreed in December 1862 to shift the venue from

For critical readings of this essay, I am grateful to Nancy R. John, Léonard Laborie, Simone Müller, and Heidi Tworek. Special thanks to Joshua Duden, Amelia Follett, Martin Klöckner, Katryn Montalbano, and Jeffrey Nichols for research assistance, and to Jennifer M. Lynch at the U.S. Postal Service Library for making available to me a copy of John A. Kasson's “Journal." 
Brussels to Paris. ${ }^{4}$ Having secured the appointment as the U.S. delegate, Kasson set out in Paris to realize the vision that had inspired his original call.

Kasson's engagement with international affairs built on his long-standing commitment to progressive politics. Over a dozen years earlier, in 1848, Kasson had been a delegate to the third-party "Free Soil" party convention that had barred slavery in the western territories owned by the United States. In 1860, Kasson had introduced a similar plank in the Republican Party platform. The "normal condition" of the territories, Kasson's plank declared, "was freedom." International postal reform provided Kasson with yet another opportunity to reenvision political boundaries to promote a cherished civic ideal.

Kasson never intimated in print that the Paris Postal Conference had anything to do with the titanic contest that was concurrently being waged in the United States between the Union and the Confederacy. In fact, the conflict went entirely unmentioned in the official transcript of the conference proceedings. This absence spoke volumes. The pivotal role of the U.S. government in organizing the conference serves as a reminder of how, even in the midst of a devastating civil war, Union administrators found it expedient to look not only westward toward the trans-Mississippi west, and southward toward the rebellious states of the Confederacy, but also eastward toward Europe. While Kasson kept the Civil War out of the proceedings, as a highranking Union official, it could not have been far from his mind. By articulating an expansive civic rationale for postal communications, he contrasted the United States not only with the European great powers but also with the Confederacy. In so doing, he invented a novel way for the United States to project its power overseas.

The Paris Postal Conference typically receives at best a brief mention in the principal histories of nineteenth-century international organizations. ${ }^{6}$ Most of these accounts emphasize its limited ambit. Though the delegates agreed on thirty-one different protocols to facilitate future bilateral postal treaties, they neither altered existing postal regulations nor established a permanent standard-setting body. Typically, the conference is treated less as an event in its own right than as a precursor to the establishment of the General Postal Union (GPU) in 1874. The GPU, which would be renamed the Universal Postal Union (or UPU) in 1878, remains today the principal standard-setting body in international postal communications.

The GPU is often described as emerging more or less organically out of a series of international postal treaties, dating back to the 1850 , that the Austrian government had ratified with various German states. ${ }^{7}$ Predictably enough, 
given this genealogy, the UPU is regarded as a German legacy, and, in particular, the brainchild of the enterprising Prussian postal administrator Heinrich von Stephan. In fact, Prussia played at best a supporting role in 1863 . Far more important was the United States, in large part because of its distinctive civic rationale for communications, that is, the presumption that access to information was a public good that governments had an obligation to facilitate more or less without regard for its cost.

The significance of the Paris Postal Conference for the history of U.S. international relations has largely gone unremarked. ${ }^{8}$ This lacuna is symptomatic of the reluctance of historians of international relations to stray beyond their traditional focus on war-making and diplomacy. ${ }^{9}$ In fact, the inner history of the 1863 conference provides a window on the influence of international relations in one realm that mattered greatly not only to merchants and government administrators but also to ordinary people. Postal protocols were highly significant not only for the few but also for the many, a group that in this period included the millions of European emigrants who had resettled in the United States.

The significance of the 1863 conference extends beyond its influence on postal policy and international relations. For it also provides a case study of the symbiotic relationship of the nation and the international, a relationship that was acquiring a heightened salience during the period when the conference occurred. Spurred by recent innovations in communications and transportation-cheap postage, the electric telegraph, the railroad, and the steamship-the nation emerged in the 1860 os as a "territorialized space." 10 Paradoxically, these innovations facilitated expansive international connections that intensified a preoccupation with the boundaries of the nation. By devising protocols for international communications, the delegates to the Paris Postal Conference affirmed the ubiquity of the spatially bounded nation as the fundamental unit in international affairs.

The heightened importance of the nation manifested itself in Paris in the principled refusal of the Paris delegates to devise protocols to facilitate postal surveillance. Postal surveillance remained a national prerogative; postal conveyance, in contrast, was increasingly envisioned as a distinctively new kind of international domain. The distinction between surveillance and conveyance was manifest in the detailed transcript of the conference's proceedings: the form in which the mail was conveyed was regulated, but not the content of the mail itself. To maintain the distinction between form and content, the delegates refused to debate the propriety of a national postal monopoly, well aware that the monopoly question was closely related to the sensitive 
issue of the kinds of materials that could, and could not, be admitted into the mail. No international body, as a Spanish delegate put it, had the authority to block a national postal administration from barring the circulation in the mail of any publication that might be inconsistent with "public order or the interests of the nation." 11

The heightened emphasis on the international dimension of postal conveyance posed a particular dilemma for the United States. The United States was at war in 1863, and the U.S. navy had since 1861 enforced a blockade that severely restricted the circulation of information between the Confederacy and the wider world. This cordon sanitaire was not absolute. Confederate diplomats, for example, could sometimes travel across the Atlantic on neutral carriers, a concession that had emerged from a potentially explosive diplomatic confrontation involving a British mail packet, the "Trent." ${ }^{2}$ Yet it did embrace the mail. Had the Paris delegates truly envisioned a transnational informational environment, questions might have arisen about the U.S. navy's informational blockade. Yet none did. For over two weeks, delegates from fifteen countries discussed international postal policy without anyone so much as once alluding to the fact that the United States was at war. The silence was deafening. By showing the flag, Kasson used an international forum both to export to the wider world a distinctively American vision of postal policy and to promote a resolutely nationalistic political agenda.

\section{THE TRANSATLANTIC CONTEXT}

While the primary impetus for the Paris Postal Conference lay in the United States, its prehistory originated in Europe, and in particular, in France, Britain, and Bremen.

French postal policy posed, for Kasson, a particular challenge. To help cover the cost of mail delivery inside France without reducing the revenue that the French post office generated for the French treasury, French postal administrators charged extremely high rates, known as "transit fees," on mail that originated outside France, and whose intended destination was outside France, but that passed through France en route to its recipient. Transit fees bore no relationship to the actual cost of transportation. That is, it cost much more to send a letter in a sealed mailbag across France from, say, the United States to Italy than to deliver a letter within France from Lille to Marseilles. Since France was a large country that was located in the middle of one of the world's most economically advanced regions, the French post office generated a large surplus from its transit fees, which it used to keep postal rates within 
France low. French government administrators defended this cross-subsidy tenaciously as a laudable wealth transfer from the rich to the poor, and by the 1860 s had enshrined it as a pillar of French postal policy.

For Kasson, France's postal policy seemed hopelessly parochial not only because it was so obviously nation-centric, but also because it was predicated on a fiscal rationale for postal policy that American lawmakers had long rejected. The primary rationale for U.S. postal policy in 1863 was civic: to increase popular access to information on market trends, public affairs, and even personal matters, lawmakers permitted the U.S. Post Office Department to run a hefty annual deficit. In France, in contrast, as in much of the world, including Great Britain, the post office remained an important source of tax revenue.

While French postal policy held few charms for Kasson, British postal policy had more to recommend it. In 1840, Britain became the first country to lower dramatically its inland letter-postage rate to increase revenue, forestall private-sector rivals in the letter-delivery market, and expand popular access to the facilities for long-distance communication. "Penny postage," as this innovation was known, emboldened postal enthusiasts in the United States to lobby for a similar reform. The comparable reform in the United States, which was enacted in 1845 and 1851, would be popularly known as "cheap postage" rather than "penny postage." ${ }^{13}$ Kasson fervently supported low and uniform postal rates and admired Britain's innovativeness in leading the way.

Cheap postage and penny postage are sometimes regarded as more or less synonymous; in fact, they had quite different rationales. The primary rationale for penny postage in Great Britain was commercial. By lowering the basic letter rate in 1840 , British postal administrators tried to match price to cost. In so doing, they shifted the rationale for British postal policy from revenue generation to commercial expansion. A lower rate, or so its proponents contended, would increase mail volume so substantially that it would facilitate trade. For this reason, the rationale for British inland postal policy in the period after 1840 is best characterized not as fiscal but as commercial.

The rationale for Britain's overseas postal policy, in contrast, like France's, remained fiscal: How much revenue could the postage on international mail generate for the state? In theory, the fiscal rationale for British overseas postal policy could be hard to justify. In explaining how postal rates for international mail ought to be computed, for example, the British delegate to the Paris Postal Conference, Frederic Hill, found himself trapped in a verbal tangle. The rates for "transit" and overseas conveyance, Hill explained, as well as "all other" postal charges, should be "as moderate as is consistent with the 
service being self-supporting and yielding a fair profit." ${ }^{14}$ Yet in practice, high transit fees remained a cornerstone of British postal policy.

In the United States, in contrast, the primary rationale for the "cheap postage" letter-rate reductions in 1845 and 1851 was neither fiscal nor commercial but civic. Contemporaries praised cheap postage not only, or even primarily, because it matched price with cost, the major rationale for postal rate reductions in Great Britain. Rather, they hailed rate reductions for facilitating the circulation of information useful for public affairs, market trends, and personal matters. Initially, the civic rationale for the low-cost circulation of information was confined to information on public affairs, a mandate dating back to the Post Office Act of 1792. In 1825, an administrative ruling briefly expanded this mandate to embrace information on market trends; following the Post Office Act of 1845 , lawmakers extended it once again to information on personal matters, such as the health of a family member or the birth of a child. ${ }^{15}$

A second feature of British postal policy to make a deep impression on Kasson was the British government's vigorous promotion of its merchant marine. To project its power overseas, the British government invested massively in what we might today call "communications infrastructure." One means to this end was the establishment of a fleet of sailing ships — the post office packetsto carry the mail. Another was the awarding of generous government subsidies to the Cunard Company, a subsidy that hastened the emergence of the Cunarders' oceangoing steamships as the dominant carrier of transatlantic mail.

The Cunarders carried the bulk of the overseas mail between Britain and America. Yet it was neither Britain, nor France, but the thriving city-state of Bremen, that established the first transatlantic bilateral postal convention with the United States. Bremen merchants were eager to expand U.S. trade, and German immigrants were flooding into the United States, giving Bremen a prominence in the Atlantic world that is often overlooked. ${ }^{16}$

The U.S.-Bremen postal convention was adopted in the summer of 1847. It facilitated the conveyance of the mail not only between the United States and Bremen, but also between the United States, Bremen, and the rest of Europe. ${ }^{17}$ The catalyst for this agreement was the first sailing of the steamship Washington from New York City to Bremen earlier that year.

Steam-powered vessels were nothing new. In fact, steamboats had for several decades operated on rivers and coastal waterways. Ocean liners, as ocean-worthy steam-powered vessels would come to be known, in contrast, remained untested, and their construction posed a technical challenge. It was in part for this reason that promoters regarded government support as essential. The Washington was one of the first two steamships to be subsidized by 
Congress under an 1845 law that, for the first time, authorized the postmaster general to contract with a steamship line to compete with Cunard in the Atlantic trade. The steamship contract went to Edward Mills, a shippingbusiness neophyte, who underbid two more credible contenders: Edward K. Collins and Robert B. Forbes. Collins operated a successful fleet of Atlantic sailing packets; Forbes owned a large fleet of ships active in the China trade.

Mills promised more for less and he got the contract. Unfortunately for the Post Office Department, he proved unable to raise even a fraction of the capital that his contract obliged him to secure, and transferred his rights almost immediately to the Ocean Steam Navigation Company, a GermanAmerican joint venture with substantial financial backing from several German states and a wealthy group of Bremen merchants. ${ }^{18}$ The Ocean Steam Navigation Company was the first steamship company to have obtained from the U.S. government a subsidy large enough to enable it to operate a regularly scheduled transatlantic service. Even so, it remained mostly a German affair. In recognition of its German backing, its principal European destination was neither Liverpool nor Southampton, but Bremerhaven, Bremen's North Sea port.

Each of the two ships that the Ocean Steam Navigation Company built, the Washington and the Hermann, were constructed by Westervelt \& MacKay in New York City, the same shipyard responsible for some of the country's most celebrated clipper ships. These steamships proved to be a disappointment to the Post Office Department. Not only did they cost more than Mills had estimated, but their sailing times failed to outpace the Cunarders. The company stumbled along until 1857, when the North German Lloyd Company, founded in that year, took over its assets and made it part of its fleet. Its brief history, however, cast a shadow on U.S. postal policy that would inform positions that Kasson adopted in Paris in 1863.

The existence of the Ocean Steam Navigation Company helped provide the U.S. minister to Great Britain, George Bancroft, with the necessary leverage to negotiate in 1848 the first bilateral postal convention between the United States and Great Britain. This agreement was less favorable to the United States than the Bremen postal convention. Yet it was even more consequential, since Great Britain was a far more important trading partner. Had the U.S. government not backed its own steamship line, Bancroft might well have lacked the clout to obtain the concessions that he did. ${ }^{19}$ The crux of the problem lay in the strikingly different rationales for mail delivery in the two countries. The British government regarded international postage as a tax, rather than a fee-for-service payment; as a consequence, government 
administrators expected postal patrons to pay British overseas postal rates even if the United States government subsidized its conveyance. ${ }^{20}$ Had the United States lacked a credible steamship company, Bancroft might well have found himself obliged to accede to the British demands. Yet the United States did have a rival in the Ocean Steam Navigation Company and thus a modicum of leverage. Bancroft underscored the distinctively American civic rationale for postal policy in arguing for a rate reduction. Newcomers from Ireland and continental Europe were flooding the United States and in Bancroft's view the U.S. government had an obligation to enable them to communicate with family and friends across the ocean. Bancroft's "sole motive" in negotiating a postal treaty, as he declared in a public letter that he issued shortly before the treaty was ratified, was to promote the "comfort and interest of the commercial world"-independent of the potential fiscal consequences of the rate reduction for the United States treasury. ${ }^{21}$

Foreigners agreed. The high rates that governments charged on international mail troubled cosmopolitan-minded public figures in many countries and led to the formation in Great Britain of the International Postage Association in 1851. The International Postage Association received a major impetus from the Crystal Palace Exhibition, a landmark international trade fair that highlighted the achievements of British commerce and industry. Backers included the English banker Lord Ashburton, the Scottish geologist Sir Roderick Marchison, the French mathematician and economist Baron Charles Dupin, and the Prussian statistician Georg von Viebahn. ${ }^{22}$

Had circumstances been different, the organizers of the International Postage Association might have spearheaded a movement to convene an international meeting of postal administrators that would have predated the Paris Postal Conference of 1863 . Yet its membership soon divided on several issues that blocked it from being an effective voice for change. For certain British postal reformers, it remained unclear if their goal was a global reduction in postal rates or merely a reduction in postal rates between Great Britain and its colonies. ${ }^{23}$ A further constraint was the assumption of postal reformers not only in Great Britain but also in France, that international postal rates should be high enough to generate a substantial surplus for the national treasury. The ubiquity of this presumption outside the United States, or so concluded an assembly of British notables convened by Lord Ashburton during the Crystal Palace Exhibition, helped to explain why the United States should take the lead in lobbying for a "system of cheap ocean-postage": the U.S. government, unlike the governments of Great Britain and France, did not regard postage as a form of taxation. ${ }^{24}$ 
The beneficial consequences for postal patrons of the American civic rationale for postal policy were well known to statesman not only in Britain but also in the United States. "Our security for the preservation of our popular institutions" - declared the textile manufacturer-turned-U.S. minister to Great Britain Abbott Lawrence in 1852, in a letter to the U.S. secretary of state Daniel Webster- "rests upon the enlightenment of the people and the extension of knowledge." And to hasten this "enlightenment," cheap postage held a key: "Perhaps nothing does more to diffuse that knowledge than the constant correspondence which takes place among the people of the United States; and were it extended to these islands [Great Britain], a corresponding advantage would be gained." ${ }^{25}$ An analogous conviction would help inspire Kasson's mission to Paris.

\section{TOWARD THE PARIS POSTAL CONFERENCE}

The civic rationale for American postal policy was but one of several factors that helped explain the willingness of the United States to take the lead in 1863. Another was military exigency. President Abraham Lincoln and his top advisors were understandably concerned that the British or French government might encourage the construction of Confederate naval vessels in their shipyards. ${ }^{26} \mathrm{~A}$ catalyst was the diplomatic firestorm that followed the capture at sea in November 1861 by a U.S. naval officer acting on his own authority of two Confederate diplomats on the British mail packet, the "Trent." The diplomats were at the time en route, respectively, to assignments in London and Paris. By taking the lead in the organizing an international conference on a topic that was seemingly distinct from the conflict raging at home, the Lincoln administration subtly signaled to the world that it remained the only legitimate power even in those sections of its territory that in 1863 were not under its direct control.

The stranglehold of the United States over the North Atlantic sea-lanes exasperated the many British and French merchants with long-standing commercial ties to merchants in seaports under Confederate control. From their point of view, Kasson's endorsement of international standards to facilitate the circulation of information across national borders rang hollow. Much more immediate was the commercial warfare that the U.S. navy was waging to block the circulation of money and information between the Confederacy and Europe. Countless letters were lost when U.S. navy vessels sank Confederate blockade runners, while many others remained marooned in the dead-letter offices in New York City and Washington, D.C., since the U.S. 
Post Office refused to deliver them to the South. ${ }^{27}$ Many contained large remittances that could not be redeemed, a major impediment to commerce. In New Orleans alone, according to France's foreign minister to the United States, between $\$ 6$ and $\$ 8$ million in remittances had been held back and awaited safe passage to Europe. ${ }^{28}$

The ostensible justification for U.S. leadership in convening the postal conference was fiscal. Like the British postal reformer Rowland Hill, Kasson intuitively grasped the elemental fact that, if he wished to rally support for postal reform, it was expedient to contend that it would improve the government's balance sheet. To settle accounts with European postal administrations, the United States government shipped a considerable quantity of gold overseas. In 1863 , the U.S. Post Office Department was running a deficit of $\$ 7$ million, much of which went to Europe to balance accounts. ${ }^{29}$ International postal reform could help staunch the outflow of gold.

While the initial justification for this conference had been fiscal, its urgency grew out of a much wider range of issues that were unrelated to postal accounting. Since the Crystal Palace Exhibit in 1851, the volume of international mail had expanded dramatically. As a result, postal administrators found it increasingly difficult to avoid expensive mistakes in rating letters and routing the mail. The mounting challenge caused by the rapid increase in mail volume obliged postal administrators to pay more attention to transborder issues. Earlier initiatives, such as the campaign by the International Postage Association's secretary Don Manuel de Ysasi to organize an international postal conference in Paris in 1855 , had failed due to widespread indifference. The association badly needed an infusion of new blood, reported one bemused observer in 1852 , since it defied reason to assume that it could forever be sustained, as it was as present, by the "clique" that had organized the 1851 Crystal Palace Exhibition: "Until they get a large admixture of non-Exhibition members, their meetings will always bear that informal colloquial character which characterizes a reunion of old soldiers, which of itself renders them unsuited to newspaper report, and deprives them of the pomp and dignity which surround a meeting of the Commissioners of Sewers." ${ }^{30}$

No prominent postal administrator played a role in organizing the International Postage Association. As a consequence, it was unsurprising that, following Ysasi's unexpected death on the eve of the 1855 Paris meetingYsasi had been a passenger on the ill-fated U.S. government-subsidized mail steamer, the S.S. Arctic, which sank in the North Atlantic-the group disbanded. ${ }^{31}$ By 1862 , in contrast, most postal administrators in the countries that sat 
astride the Atlantic sea-lanes had realized that something had to be done. Ironically, the promulgation of international postal protocols would be the work of nationally based postal administrators. Over half of the fifteen delegations in attendance at the Paris conference-including those from the United States, France, Great Britain, Prussia, Switzerland, Belgium, Italy, and the Netherlands-were headed up by postal administrators, or, in the case of the United States, a former postal administrator, since Kasson had recently won election to Congress. The others were headed up by diplomats, with the exception of the delegation from the Sandwich Islands (Hawaii), which was represented by the peripatetic British political economist John Bowring.

A final impetus for the 1863 conference lay in the elusive realm of ideals. The "cheap postage" movement in the United States and the "penny postage" movement in Great Britain had popularized the notion that low and uniform postage promoted the public good. Kasson was determined to show how the benefits of postal reform could be realized not only in one country, but also across national boundaries. To this end, Kasson hoped to establish an international consensus to lower international postal rates, increase their uniformity, and simplify transnational postal accounting. ${ }^{32}$ Like Elihu Burritt, the stalwart American-born proponent of "ocean penny postage," Kasson was inspired by the idealism of the many merchants, ministers, and peace activists who had become persuaded of the nineteenth-century variant of the digital-age mantra that "information wants to be free." 33

\section{DEVISING INTERNATIONAL STANDARDS}

In his quest to eliminate the barriers impeding the international circulation of information, Kasson often found himself allied with the delegates from Italy, Switzerland, and Prussia, and in opposition to the delegates from Great Britain and France. Though the British and French differed on many points, they shared a propensity, which Kasson found exasperating, to subordinate the collective good to parochial concerns. The delegates from both countries, Kasson fumed in the remarkably candid personal journal that he kept during the conference, displayed a "pertinacious disposition" to challenge the application of "every acknowledged postal principle" that conflicted with their country's "financial interests" or where the "preponderance of benefit" from the universal adoption of this principle would favor a "foreign nation." ${ }^{34}$ Both defended high transit fees; the British also hoped to retain high postage rates on overseas mail transported in British steamships. "Self-interest," Kasson confided in his journal, "stands evidently at both the gates of Europe."35 
The French found the retention of high transit fees so fiscally important that Kasson conceded that it might well be necessary to make "some allowance" for the "warmth of her delegates upon this point." ${ }^{36}$ In Kasson's view, transit fees should never exceed the postage charged for transporting "domestic" mail, eliminating the principle, which was particularly important in France, that the revenue generated by transit fees subsidize cheap postage inside the country. ${ }^{37}$ Yet when the issue of transit fees came up for discussion, the French delegate, Édouard Vandal, who also chaired the conference, left the room, informing his colleagues that his superiors had prohibited him from so much as participating in the discussion of such a sensitive topic. ${ }^{38}$

The obstreperousness of the British delegate, Frederic Hill, was, in certain respects, even more unsettling. Early on in the conference, Hill privately told Kasson that he wanted Britain and the United States to have "as much concurrence in our action as possible." ${ }^{39}$ On the face of it, this seemed like a good plan. The "penny postage" scheme that Great Britain had enacted in 1840 was well known around the world, a particular point of pride for Hill, not only because Hill himself was a British postal administrator but also because its prime mover, Rowland Hill, was Hill's brother. Even so, Frederic Hill displayed what Kasson regarded as an infuriating solicitude for retaining high transit fees for mail transported overland inside Great Britain as well as overseas by the Cunarders. Government steamship subsidies, in Kasson's view, had been instituted "more in the interest of commerce" than the mail, and thus should not be paid for by postal patrons. ${ }^{40}$

The retention of onerous transit fees for steamship service troubled Kasson not only because they were unrelated to the actual cost of transporting the mail, but also because they varied from steamship company to steamship company, complicating the task of establishing a uniform rate. The high cost and complexity of transatlantic postage had bedeviled American postal patrons for many years. Kasson was determined to exert whatever leverage he could to establish an international consensus that would facilitate the negotiation of bilateral treaties that would lower rates and ensure their uniformity. No issue was of more pressing concern to the American merchants with whom Kasson had met in Paris before the conference, or the journalists who followed its proceedings in the United States. ${ }^{41}$ The delegates should not get bogged down in the "fog of European differences", complained one Philadelphia editor, when the "main object" was establishing low and uniform transatlantic rates: "They may make what arrangements they deem fit as to the crossing of national boundaries in Europe, but we have great interest in establishing a better system of communication with them in general." ${ }^{42}$ 
Kasson's frustration with Hill was exacerbated by his weak bargaining position. The British government in 1863 subsidized the mighty Cunaders; the U.S. government, in contrast, had by then left the subsidy business altogether. The differential investment of the British and the Americans in oceangoing mail steamships greatly troubled Kasson, since he regarded steamship subsidies not only as a bargaining chip but also as a catalyst for economic development. It was his “earnest opinion," or so Kasson informed New Zealand postal administrator Crosbie Ward, that the subsidization of a line of "mail and commercial" steamships on the Pacific Ocean was indispensable to the future commercial expansion of the United States. "I believe," Kasson elaborated, that a "connected system of such communication" from San Francisco, via the Sandwich Islands, to Japan and China, and from Panama southward to Australia and New Zealand was a "necessity" that the United States must "soon appreciate" as "alone capable of making our country the financial and commercial centre of the world." 43

The high expectations with which Kasson had invested cheap postage helps to explain his exasperation at Frederic Hill's ultimately unsuccessful attempt to back down from the radical proposal that Hill himself had made to limit transit rates to one half the "interior" rates on the same route, a proposal that had been approved by a subcommittee on which both Hill and Kasson served. ${ }^{44}$ Though Hill publicly supported a "liberal" agenda, Kasson recognized that Hill retained many misgivings about the "more liberal resolutions" to which the delegates had agreed, and predicted that, as the head of the foreign desk at the British post office-which, among other things, put him in charge of steamship policy-Hill would oppose them if they conflicted with "English usage." Indeed, Kasson feared that this criticism might "even apply to his [Hill's] connection with the transit resolution, which was his own proposition." ${ }^{45}$

For Kasson, the transit fee issue was intimately connected to other, less contentious matters. Prominent among them was the establishment of an international standard for the weight of a single letter; the articulation of uniform accounting protocols for mail that crossed multiple national boundaries; and the adoption in the United States of the metric system, a reform that Kasson hoped the postal conference would promote. Yet the transit issue remained key. The best way to ensure that one nation would not beggar its neighbor by insisting on outrageously high transit fees, in Kasson's view, was to peg transit fees to domestic postal rates. If this principle were adopted, then postal patrons in foreign countries would obtain a "certain kind of protection" from extortionate charges since they would have the 
benefit of "whatever responsibility existed" with regard to the "like charges" that the government assessed on "its own subjects or citizens." ${ }^{46}$

Kasson's linkage of transit fees with domestic postal rates illustrated the interdependence of international postal standard-setting bodies and national postal administrations. To increase popular access to the mail, national governments lowered their internal postal rates. Having done so, and unless they wished to countermand the protocols agreed upon in Paris, they had no choice but to peg domestic postal rates to the transit fees that they charged on mail that traveled through their territory en route to its final destination.

The linkage Kasson envisioned between domestic and international postal rates would take over a decade to institutionalize. In the meantime, U.S. postal administrators found themselves at the mercy of Great Britain and France. To solve this problem, Kasson worked with the Belgian and Prussian delegates to reroute the large volume of mail currently being sent to and from the multitudes of Germans and Scandinavians who had emigrated to the United States. If postal administrators in Europe sent the "social correspondence" of the Germans and the Scandinavians on the Bremen- and Hamburgbased mail Atlantic steamers, rather than on the Cunarders, it would significantly lower its cost, since the German steamship lines charged a mere 10 cents per letter, far less than Cunard. True, the mail would cross the Atlantic more slowly on a German steamer. For this reason, time-sensitive merchants were likely to stick with the faster, more expensive Cunarders. For the vast majority of postal patrons, however, speed was of "much less importance" than the cost of conveyance. ${ }^{47}$

Kasson's expansive interpretation of the civic rationale for postal communications won him the plaudits of several conference delegates. In contrast to the postal systems of the "great majority of countries," or so the Swiss delegate admiringly observed, the U.S. postal system was not expected to generate a surplus for its government. As a consequence, as the French delegate Édouard Vandal perceptively declared, its policy was "exceptional." Limiting the transit rate to one-half the inland rate was an "immense step forward"; even so, Vandal reassured his French colleagues, the lower transit rate was still high enough to ensure the French treasury a "handsome profit." 48

While the 1863 conference did not resolve all of the issues troubling Kasson, it proved remarkably successful at establishing protocols that, in the next few years, would be institutionalized in bilateral postal treaties between most of the world's most commercially advanced nations. All in all, the delegates agreed to thirty-one "rules," as the protocols were termed in the Englishlanguage transcription of the conference proceedings that the U.S. postmaster 
general printed in his 1864 annual report. These protocols divided the mail into six "classes," established uniform procedures for postal accounting, designated a common standard of measurement (the "metrical decimal system"), and specified a maximum weight for a single international letter (15 grams). Conveniently for Great Britain and the United States, which remained on the rival avoirdupois ( 16 ounces to a pound) measurement system, this weight maximum was basically identical to one-half an ounce, minimizing any potential disruption.

Among Kasson's greatest achievements was the inclusion in the conference proceedings of a strongly worded clause that derided high transit fees as an "insurmountable obstacle" to establishing an "international system of correspondence" on conditions "advantageous to the public." Henceforth, the delegates agreed, transit fees on foreign letters should "never" exceed one-half the rate of that on inland postage. ${ }^{49}$ Kasson's achievement was all the more impressive given the fact that the United States had no fleet of governmentsubsidized steamships to use as a bargaining chip: ideas rather than interests carried the day.

To reduce Kasson's achievement to a mere list of proposals, however, obscures their true character. In international postal negotiations, the United States enjoyed the moral high ground by virtue of the expansiveness of its civic rationale for postal policy. The distinctiveness of this rationale was obvious to every well-informed student of postal affairs. Yet it was Kasson who transformed it into protocols that would eventually be embraced by an international standard-setting body. "Let us not forget, gentlemen," Kasson declared, in a brief speech that he delivered on the final day of the conference, "the extent of the interests involved in some degree in our enterprise":

The mails carry those orders, which create foreign commerce, sustain the commercial marine, and aid largely in the development of interior industry. They exchange the missives which are so necessary to the interests of family, of kindred and of friendship, and upon which so much of the happiness of our race depends. They diffuse the printed elements of civilization, progress, and intelligence. In each of these ways, they serve to break down the useless barriers which ignorance and non-intercourse formerly interposed between nations. They are the initiators of a durable condition of international peace and prosperity. To facilitate these great results, while at the same time we promote the immediate convenience of the public - this has been our mission..$^{50}$ 
By internationalizing the civic rationale for U.S. postal policy, Kasson gave the Paris conference a mandate that was far more ambitious than the sum of its parts.

The biggest disappointment of the conference for Kasson, as well as his colleagues in the like-minded Italian and Swiss delegations, was the failure to eliminate route-based rate differentials, an outcome that was probably due to backroom maneuvering by Frederic Hill. Even here, however, the delegates took a major step toward their elimination, by stipulating that, whenever "intermediate charges" rendered it "practicable," the rates on international correspondence should be uniform, independent of the routes over which the mail might be conveyed.$^{51}$ In the years to come, the protocols Kasson helped devise in Paris would become institutionalized in postal policy, first in bilateral treaties, and eventually in multilateral accords.

\section{A LIBERAL TRADITION}

The Paris Postal Conference received respectful, if often cursory, attention in the British and American press. Its delegates seem to have arrived at a "good understanding of the principles of postal reciprocity," declared one British postal administrator in 1864, and "good will doubtless be the result." The "Postal Congress" was a "Peace Congress" of the "most efficient kind," the administrator added, "and in every sense of the term." ${ }^{52}$ The American press emphasized Kasson's "liberal" vision of international communications, a characterization that Kasson himself embraced. ${ }^{53}$ Particularly admirable, in the opinion of the Washington, D.C.-based National Intelligencer, had been Kasson's determination to follow up the achievements of the conference with the negotiation of bilateral postal treaties with several countries, including Belgium, Italy, and Switzerland. In so doing, he had given "practical effect" to the "liberal movements initiated at the International Conference."

The civic rationale for American postal policy that Kasson invoked in 1863 had been for several decades a subject of frequent discussion by the small yet dedicated cadre of American journalists who had made a special study of postal policy. Foremost among them was Joshua Leavitt, a Congregationalistminister-turned-newspaper editor who had long written on postal topics for the Independent, an influential religious newspaper based in New York City. Leavitt had followed postal affairs closely since the 1840s, when he had lobbied lawmakers to emulate Rowland Hill's experiment with penny postage. Frustrated by the refusal of Congress in 1845 to reduce the basic inland letter rate to 1 cent-the basic inland letter rate would be reduced to 5 and 10 cents 
in 1845 , depending on distance, and to a flat 3 cents for most of the United States in 1851-Leavitt repeatedly lectured the public on the distinctiveness of the U.S. government's civic mandate to circulate information over long distances at low cost. The "language of the Constitution," Leavitt pontificated in 1862, enshrined the presumption that information-and, in particular, the information contained in newspapers - should be circulated at the lowest practicable rates. In this way, it helped ensure that the postal system would remain a "great enginery of governmental wisdom and beneficence" conducted for the "public good" to promote the "widest diffusion of intelligence." 55

Leavitt had no doubt that "intelligence" embraced not only newspapers, but also personal correspondence, which, by an analogous logic, should also be circulated at the lowest possible rate. Should Congress reduce the inland letter rate to 1 cent, Leavitt predicted, this would massively increase the circulation of inland letters through the postal system, enabling the United States to equal Great Britain in mail volume, a benchmark that Leavitt regarded as proof that the republican United States could match its monarchical parent. ${ }^{56}$ The post office, Leavitt declared in an essay on Anglo-American commercial solidarity that he successfully entered in 1868 in a prize competition administered by free-trade-oriented English Cobden Club, was "beyond a question, the most perfect piece of governmental machinery that was ever invented," and the establishment of cheap ocean postage between Britain and America would be likely, if "continued for a generation," to "render a bloody war between the two nations unimaginable." ${ }^{57}$

Yet even committed postal visionaries such as Leavitt were long reluctant to wholeheartedly endorse cheap ocean postage. In this regard, as in his quixotic endorsement of the metric system, Kasson's position was unusually advanced. Unlike the stalwart cheap-postage champion Elihu Burritt, Leavitt would not editorialize in favor of cheap ocean postage in the Independent until after the inauguration of Ulysses S. Grant in March 1869. And unlike Kasson, Leavitt would remain far more committed to lowering domestic postal rates than to lowering the transit fees on mail sent from country to country.

\section{LEGACIES}

In the end it would not be a national government, but an international organization that institutionalized the protocols regulating overseas mail that brought cheap postage to the world. This organization owed a major debt to the linkage by an American postal administrator-turned-lawmaker of national prerogatives and international standard-setting. Kasson had not intended the 
1863 Paris Postal Conference to lead directly to an international postal organization, and it did not. The "idea" of the United States in calling for the meeting, or so Kasson explained in a public statement that he gave during its opening day, was not to "bind" the countries who had sent delegates, but, rather, "simply to examine a certain number of questions, whose solution would facilitate the negotiation of postal treaties." 58 It would take eleven years before delegates met in Berne, Switzerland, to establish the General Postal Union (GPU), the international standard-setting body that, following its transmogrification into the Universal Postal Union (1878), would finally establish the binding international postal protocols that have rendered bilateral postal treaties obsolete. ${ }^{59}$

The 1863 Paris Postal Conference was but one of a series of events that led to the founding of the UPU, and with it, international standards for circulating letters, newspapers, and, eventually, parcels. Yet it is worth remembering for at least two reasons that had nothing to do with UPU genealogy. Most obviously, it thrust the United States onto the world stage at an unusually precarious moment in its history. In the summer of 1863 , the future of the republic remained to be decided on the battlefield and the possibility that one or more European powers might establish diplomatic relations with the Confederacy could not be discounted. Though there is remarkably little direct evidence linking Kasson with the Lincoln administration's diplomatic strategy, he could not have been unaware of the extent to which the very fact that the U.S. government had convened an international meeting in the heart of Europe in the midst of a devastating civil war reminded the great powers that the United States was a player on the world stage and that the Confederacy was not.

The power that the United States projected at the postal conference had little to do with its commercial prowess. The U.S. government in 1863 no longer commanded its own fleet of mail steamers, as, for example, it had in 1848: U.S.-backed transatlantic mail steamship service had been suspended during the war. It was, similarly, unrelated to its military muscle. The United States was so weak militarily that the Lincoln administration found it impossible to retain two Confederate diplomats whom a U.S. naval commander, acting on his own authority, had captured on a British mail steamship in international waters. Though the Confederate diplomats had been trying to obtain British and French recognition for the Confederacy, the Lincoln administration found itself stymied not only by hostile international public opinion, but also by the very real possibility that, had it refused to give the Confederate diplomats up, it might well have provoked war with Great Britain, then the leading naval power in the world. 
The power that the United States projected, rather, lay in the realm of ideas, or what a present-day political theorist might call "soft power." The primary rationale for the 1863 Paris Postal Conference, Kasson declared, in his closing remarks, had been to remove "obstacles to uniformity, simplicity, and cheapness in international postal intercourse," and, to an extent that was greater than their "fears" had permitted them to anticipate, its delegates had drafted protocols for international postal arrangements that had done much to "remove them."60

The capacious civic rationale for postal policy that Kasson championed in his address to his fellow delegates distinguished the United States from the Confederacy, whose Constitution specifically forbade postal subsidies and mandated that all postal expenses be paid for out of general revenue. ${ }^{61}$ In addition, it identified the United States with a mission more elevated than self-preservation, less controversial than popular self-government, and more plausible than abolition. By advocating the establishment of international postal protocols, Kasson projected outward a compelling civic ideal. Just as the American West ought to be free from slavery, as Kasson had posited in the 1860 Republican Party platform; so, too, international communications should be liberated from the parochialism of nation-centric postal policies that inhibited commerce and mutual understanding. Here, as in so many other realms, national prerogatives and international standard-setting went hand in hand. ${ }^{62}$

The legacy of postal policy is easily forgotten. For example, it has for some time been a commonplace to trace back the genealogy of present-day digital communications networks not to the mail, but instead to the electric telegraph. In its baldest formulation, journalists proclaim the electric telegraph the "Victorian Internet." ${ }^{63}$ In fact, however, this analogy is flawed for at least two reasons. First, it was the mail, and not the electric telegraph, that enabled ordinary people to transmit messages around the world at high speeds and on a regular schedule at an extremely low cost. Electric telegraph rates remained far too high to be practical for international communications. ${ }^{64}$ Second, the impetus for this innovation lay not in Victorian Great Britain, but in the republican United States.

"Cheap postage" lacks moral resonance today. Even so, in the Atlantic world of 1863 it remained a phrase to conjure with, and helps to explain why, at such a seemingly unpropitious moment in its history, the United States took the lead in hastening the promulgation of international standards in a realm that was seemingly so far removed from the pressing needs of the day. Nineteenth-century liberalism differed in many ways from its twentiethcentury stepchild. Yet it was no less infused with a fervent faith in the utopian 
proposition that collective experiments in social engineering could remake the world. Politics have artifacts. ${ }^{65}$ Like the Atlantic cable-or the mail steamshipcheap postage was not only or even primarily a technical advance. Rather, it was a cultural expression of a compelling civic ideal.

\section{Columbia University}

\section{NOTES}

1. "International Postal Conference," in Twenty-Eighth Annual Report of the Post Office Department of the United States . . 1863 (Washington, D.C., 1864), 164.

2. Confusion persists even with respect to nomenclature. The U.S. delegate, John A. Kasson, consistently termed the meeting a "conference," a practice followed here. In the U.S. press, however, the meeting was often termed a "convention"; in France and England, in contrast, it was sometimes termed a "commission" or a "congress." The term "convention" linked the meeting with social reform; "commission" and "congress" with diplomacy. For "Postal Convention," see “The Postal Puzzle," Philadelphia Inquirer, 5 December 1862; "Postal Convention," Baltimore Sun, 10 July 1863; "The International Postal Convention," Springfield Republican, 29 August 1863. For "commission," see Commission Internationale des Postes (Paris: Impériale, 1863); "Letter from Paris," 23 June 1863, in Milwaukee Sentinel, 11 July 1863; "The International Postal Congress," Manchester Guardian, 6 June 1863.

3. Compte rendu des travaux du Congrès général de statistique: réuni à Bruxelles les 19, 20, 21, et 22 Septembre 1853 (Brussels, 1853), 94, 236-37.

4. John A. Kasson to William Seward, 31 December 1862, United States Postal Service Library, Washington, D.C. (hereafter USPSL-DC).

5. John Kasson, "An Autobiography," Annals of Iowa 12 (July 1920): 349; Edward A. Younger, John A. Kasson: Politics and Diplomacy from Lincoln to McKinley (Iowa City, 1955), 104.

6. See, for example, Francis Lyall, International Telecommunications: The International Telecommunications Union and the Universal Postal Union (Farnham, UK, 2011), 229-31, and F. S. L. Lyons, Internationalism in Europe, 1815-1914 (Leyden, 1963), 44-45.

7. The most authoritative English-language account of the conference remains George A. Codding Jr., The International Postal Union: Coordinator of International Mails (New York, 1964), 20-24, which can be supplemented by Léonard Laborie, L'Europe mise en réseaux: La France et la coopération internationale dans les postes et les télécommunications (Brussels, 2010), chap. 2. Other accounts include Marc Moser, 10o Jahre Weltpostverein (Frankfurt am Main, 1974-75); Younger, John A. Kasson, chap. 9; John F. Sly, "The Genesis of the Universal Postal Union: A Study of the Beginnings of International Organization," International Conciliation 233 (October 1927): 395-436; and C. J. Beelenkamp, Les lois postales universelles (Havre, 1910), 531-50. Moser, Younger, and Beelenkamp had access to a copy of the official proceedings of the conference; Sly did not (Sly, "Genesis," $424 \mathrm{fn} \mathrm{20}$ ). No previous scholar has had access to Kasson's personal journal, which has long been retained among the miscellaneous records of the U.S. Postal Service Library in Washington, D.C. The librarian of the U.S. Post Office Department briefly contemplated publishing Kasson's 
journal in conjunction with the centennial of the Paris Postal Conference in 1963. The librarian demurred, however, after he read through the document, fearful that, though a century had passed, Kasson's "pithy and sagacious comments" about the other delegatesKasson had much, in particular, to say about the French and the British-might "possibly strain international relations." Xenophon P. Smith, memorandum, 24 August 1962, USPSL-DC.

8. The conference goes unmentioned, for example, in George C. Herring's From Colony to Superpower: U.S. Foreign Relations since 1776 (New York, 2008).

9. Exceptions include Justin Hart, Empire of Ideas: The Origins of Public Diplomacy and the Transformation of U.S. Foreign Policy (New York, 2013); Ian Tyrrell, Reforming the World: The Creation of America's Moral Empire (Princeton, 2010); and Frank Ninkovich, Global Dawn: The Cultural Foundation of American Internationalism, 1865-189o (Cambridge, Mass., 2009).

10. Charles S. Maier, Leviathan 2.o: Inventing Modern Statehood (Cambridge, Mass., 2012), chap. 2.

11. "International Postal Conference," in Twenty-Eighth Annual Report of the Post Office Department, 118-20.

12. David Paull Nickles, Under the Wire: How the Telegraph Changed Diplomacy (Cambridge, Mass., 2003), chap. 3.

13. Richard R. John, "The Political Economy of Postal Reform in the Victorian Age," Smithsonian Contributions to History and Technology 55 (2010): 3-12.

14. Frederic Hill, Postal Conference, May 1863, in Kasson, "Journal," USPSL-DC.

15. Richard R. John, "Expanding the Realm of Communications," in An Extensive Republic: Print, Culture, and Society in the New Nation: vol. 2 of A History of the Book in America, ed. Robert A. Gross and Mary Kelley (Cambridge, 2010), 211-20; John, Spreading the News: The American Postal System from Franklin to Morse (Cambridge, Mass., 1995), chap. 2. The extension of the civic rationale for postal policy to embrace the circulation of parcels was highly controversial and, when this issue first found its way onto the public agenda in the 1870s, met with vigorous opposition. "If Congress proposes to go into the business of transporting dry goods, groceries, and harnesses in four-pound packages," declared an editorialist in 1876 who was otherwise sympathetic to low-cost mail delivery, "it should, at the very least, charge enough to pay the expenses. We doubt the expediency of going into the [parcel delivery] business at all. . . The cheapest rate of postage can be attained best by confining the mail to its proper business." "The Postal Question," Independent, 20 April 1876.

16. Lars Maischak, German Merchants in the Nineteenth-Century Atlantic (Cambridge, 2013), chap. 5.

17. George E. Hargest, History of Letter Post Communication Between the United States and Europe, 1845-1875, 2nd ed. (Lawrence, Mass., 1971), chap. 1.

18. Maischak, German Merchants in the Nineteenth-Century Atlantic, 142.

19. I owe this insight to Peter A. Shulman.

20. Lilian Handlin, George Bancroft: The Intellectual as Democrat (New York, 1984), 232.

21. George Bancroft to Lord Clanicarde, 11 February 1848, in James K. Polk, "Message from the President, Communicating the Correspondence between the United States Minister at London and Authorities of the British Government, In Relation to a Postal Arrangement between the Two Countries," Sen. Ex. Doc. 30, 30th Cong., 1st sess., 1848 (serial 506), 35.

22. Living Age, 13 September 1851; Laborie, L'Europe mise en réseaux, 89. 
23. Henry Derecourt, Colonial and International Postage: A Collection of Extracts, Ideas, and Information on Postal Affairs, and Post Office Anomalies (London, 1854), 8.

24. Abbott Lawrence to Daniel Webster, 7 May 1852, in Hamilton Andrews Hill, Memoir of Abbott Lawrence, 2nd ed. (Boston, 1884), 233.

25. Lawrence to Webster, in Hill, Memoir, 232.

26. Herring, From Colony to Superpower, chap. 6; Warren F. Spencer, The Confederate Navy in Europe (University, Ala., 1983), esp. 89-9o.

27. London Morning Chronicle, 28 September 1861, 5; "The Southern Confederacy," London Times, 27 December 1862, 7; “The Civil War in America," London Times, 30 May 1862, 9; E. M. Hudson, The Second War of Independence in America (London, 1863), vi.

28. Henri Mercier to William Henry Seward, January 1862, in Abraham Lincoln, "Annual Message of the President," H. Ex. Doc. 1, 37th Cong., 3rd sess., 1862 (serial 1156), 408.

29. Younger, John A. Kasson, 142.

30. "International Postage," Spectator, 14 August 1852, 780.

31. "Address," Journal of the Society of the Arts and of the Institutions in Union 3 (17 February 1854): 7.

32. Younger, John A. Kasson, chap. 9.

33. On Burritt, see Peter Tolis, Elihu Burritt: Crusader for Brotherhood (Hamden, Conn., 1968).

34. Kasson, "Journal," 25 May 1863 , USPSL-DC.

35. Kasson, "Journal," 26 May 1863, USPSL-DC. The "gates" of Europe, in Kasson's view, did not include Spain and Portugal, presumably because they had few steamship connections, and thus in comparison with their neighbors, were of the "least postal importance." Kasson, "Journal," 2 June 1863, USPSL-DC.

36. Kasson, "Journal," 21 May 1863, tipped-in letter, USPSL-DC.

37. Kasson, "Journal," 19 May 1863, USPSL-DC.

38. Kasson, "Journal," 30 May 1863, USPSL-DC.

39. Kasson, "Journal," 10 May 1863, USPSL-DC.

40. Kasson, "Journal," 19 May 1863, USPSL-DC.

41. Among the American merchants active in overseas trade with whom Kasson met with in London and Paris in the days immediately preceding the 1863 conference were John Murray Forbes and William H. Aspinwall. Kasson, "Journal," 9, 12 May 1863, USPSL-DC; Worthington Chauncey Ford, ed., A Cycle of Adams Letters, 1861-1865 (Boston, 1920), 400.

42. "International Postal Regulations," Philadelphia North American, 6 June 1863.

43. Kasson, "Journal," 27 May 1863, USPSL-DC.

44. Kasson, "Journal," 19, 22 May 1863, 2, 4 June 1863, USPSL-DC. The members of this subcommittee consisted of the delegates from five countries: Great Britain, France, the United States, Prussia, and Switzerland.

45. Kasson, "Journal," 3 June 1863, USPSL-DC.

46. Kasson, "Journal," 30 May 1863, USPSL-DC.

47. Kasson, "Journal," 26 May 1863, USPSL-DC. Kasson was by no means alone in prioritizing low cost over high speed. "Cheap postage is a blessing more especially to the poor and the emigrant," editorialized the New-York Tribune in discussing a postal treaty with Great Britain: "To them a difference of forty-eight hours in time is nothing, but a difference of nine cents in money is a great deal. The proportion of business letters which 
require speed in transmission, we are credibly informed, is to other letters not more than as one to nine." "The British Postal Treaty," New-York Tribune, 20 February 1868.

48. "International Postal Conference," in Twenty-Eighth Annual Report of the Post Office Department, 144-45.

49. Montgomery Blair, "Annual Report of the Postmaster General," H. Ex. Doc. 1, 38th Cong., 1st sess., 1863 (serial 1184), 9.

50. "International Postal Conference," in Twenty-Eighth Annual Report of the Post Office Department, 164.

51. Kasson, "Journal," 30 May 1863, USPSL-DC.

52. William Lewins, Her Majesty's Mails: An Historical and Descriptive Account of the British Post-Office (London, 1863), 183.

53. "International Postal Regulations," Philadelphia North American, 6 June 1863; "The International Postal Convention," Washington Daily National Intelligencer, 21 August 1863; "The International Postal Convention," Boston Daily Advertiser, 24 August 1863.

54. "The International Postal Convention," Washington Daily National Intelligencer, 21 August 1863 .

55. “Thorough Postal Reform," Independent, 13 February 1862. Most Independent editorials, like this one, were unsigned. Leavitt's authorship can be inferred from its vigorous style, the self-assurance with which it tackled arcane postal topics, and its allusion to the newly appointed Boston postmaster, John Gorham Palfrey, a longtime acquaintance. Leavitt served as managing editor of the Independent from its founding in 1848 until his death in 1873; during this period he wrote many editorials on postal topics.

56. "New Postal Project," Independent, 10 July 1862.

57. Joshua Leavitt, An Essay on the Best Way of Developing Improved Political and Commercial Relations between Great Britain and the United States of America (London, 1869), 20, 23.

58. "International Postal Conference," in Twenty-Eighth Annual Report of the Post Office Department, 111.

59. Codding, Universal Postal Union, chap. 2

6o. "International Postal Conference," in Twenty-Eighth Annual Report of the Post Office Department, 164.

61. Judah Benjamin to James M. Mason, 15 January 1863, Official Records of the Union and Confederate Navies in the War of the Rebellion, ser. 2 (Washington, D.C., 1922), vol. 3, 650.

62. Mark Mazower, Governing the World: The Rise and Fall of an Idea, 1815 to the Present (New York, 2012).

63. The originator of the facile, question-begging, and maddeningly anachronistic characterization of the nineteenth-century electric telegraph network as the "Victorian internet" is Tom Standage, The Victorian Internet: The Remarkable Story of the Telegraph and the Nineteenth-Century's On-line Pioneers (New York, 1998).

64. Simone Müller-Pohl and Michaela Hampf, Global Communication Electric: Business, News, and Politics in the World of Telegraphy (Frankfurt am Main, 2013); Richard R. John, Network Nation: Inventing American Telecommunications (Cambridge, Mass., 2010), chaps. 4-5.

65. For a related, though distinct, formulation of the relationship between politics and artifacts, which posits a causal relationship not from politics to artifacts, but the other way around, see Langdon Winner, "Do Artifacts Have Politics?" Daedalus 109 (Winter 1980): 121-36. 